\title{
Benefícios Previdenciários à Concubina Diante do Estatuto do Divorcio.
}

\author{
R. Limongi França \\ Membro da Academia Brasileira de Letras Jurídicas
}

\begin{abstract}
Sumário: I - o Concubinato no Direito Brasileiro. 1. Conceito e Terminologia. 2. Espécies de Concubinato. 3. Funşâa Sócio-Jurídica do Concubinato. 4. Tendência Fundamental do Direito Positivo. 5. Direitos Vedados ao Concubinato. 6. Direitos assegurados ao Concubinato. II - OS BENEFícios PREVIDENCIArios Concedidos à Concubina. 1. Visāo Geral. 2. A Condiģão de Dependente. 3. Benefícios a Que Tem Direito. 4. A Pensão por Morte. III - 0 Advento do Drvórcio. 1. Conceito de Divórcio. 2. Paralelo entre o Divórcio e Institutos Afins. 3. Referências Históricas. 4. Texto da Emenda Constitucional n. 9. 5. $O$ art. $1 .^{\circ}$ da Emenda n. 9. 6. $O$ art. 2.० da Emenda n. 9. 7. A Lei Ordinária do Divórcio. IV - Os Benefícios Previdenciários a Concubina Diante do Estatuto do Divórcio. 1. Perspectivas Jurídicas do Concubinato. 2. Consideraçōes Sobre Essas Perspectivas, Quanto ao Aspecto Previdenciário. 3. O Mesmo, ao Depois da Lei do Divórcio. V - Conclusão.
\end{abstract}

1. Conceito e terminologia. Concubinato vem diretamente do latim - concubinatus-us, que SANTOS SARAIVA (Novissimo Dicionário Latino-Português, p. 271), baseando-se em PlaUto E SUETôNio, traduz por "mancebia, concubinato, abarregamento"

Ao seu turno, concubinatus vem do verbo concubo-are ou concumbo-ere, cujo sentido é o de - "deitar-se, encostar-se juntamente, ou ao pé de" — "ter comércio, cópula carnal com" (op. cit.).

Segundo um texto de Paulus, que se encontra no De Verborum Significatione (D. 50, 16, 144), os antigos chamavam pelice àquela que vivia com alguém, embora não lhe fosse a esposa - quae, cum uxor non esset, cum aliquo tamen vivebat; então chamada amiga, ou, mais decentemente, concubina quam nunc vero nomine AMICA, paulo honestiare CONCUBINAM appelari. 
O mesmo fragmento traz a lição de GraniUs Flacus, o qual, no Jus Civile Papinianus reafirma a acepção vulgar de pelice e ensina a origem grega da palavra "concubina"

Por diversas fases passou o concubinato no próprio Direito Romano.

Constituindo um tipo de comunidade conjugal ao qual faltava algum dos requisitos do matrimônio, distinguiu-se sempre deste pela ausência do honor matrimonii, de tal forma que a mulher não se chamava uxor nem vir o homem, além da inferior condição dos filhos (JörS-KUNKEL, op. cit., § 178; SERAFINI, Istituizioni di Diritto Romano, II, p. 160-161; WALDEMAR César DA SILVEIRA, op. cit.).

Numa certa fase, era a única forma possível de união com libertos, sem infringir a Lex Julia de Adulteris, promulgada por AUGusto.

Vários textos se ocupam com a sua disciplina, no sentido de proibir o concubinato a quem já possui mulher, bem assim a pluralidade de concubinas (cf. FIEFFE-LACROIX, La Clef des Lois Romaines I, p. 84, Metz, 1809). Com efeito, é célebre regra do Codex, 5, 26, 1, De Concubinis, segundo o qual - nemini licentia concedatur, constante matrimonio, concubinam penes se habere (Constantinis, patre et filio, 320).

Com os monarcas cristãos, passou não só a considerar-se imoral, mas ainda a ser objeto de estímulos, como a legitimação, com o fito de se regularizar através das justas núpcias.

Com JUSTINIANo (v. JöRS-KUNKEL), teria assumido a condição de uma espécie de matrimônio de grau inferior.

$O$ conceito atual de concubinato pode considerar-se, fundamentalmente, o mesmo do De Verborum Significatione, do Digesto, e que assim proporíamos fosse enunciado: é a união constante do homem e da mulher, sem o matrimônio civil regular.

Chama-se concubina a mulher que participa do concubinato.

Mas, também se diz concubino o homem que se encontra nas mesmas circunstâncias.

Aquela e este se denominam outrossim companheira e companheiro.

2. Espécies de concubinato. O concubinato pode dividir-se fundamentalmente em duas espécies:

I - Natural.

II - Espúrio. 

didas.

Natural é o concubinato entre pessoas livres e desimpe-

Espúrio é aquele em que ambos os concubinos ou apenas um deles está legalmente impedido de casar-se.

Pode ser :

A) Adulterino.

B) Incestuoso.

Adulterino, aquele em que o impedimento se funda no próprio estado de cônjuge de um ou de ambos os concubinos.

Incestuoso, aquele em que o impedimento se funda no parentesco próximo entre os concubinos.

Em Direito Canônico haveria a considerar o concubinato sacrílego; isto é, aquele em que um ou ambos os concubinos tomaram votos de castidade.

Não se considera espúrio ou adulterino o concubinato entre pessoas desquitadas ou das quais uma é desquitada e a outra é livre.

Pode distinguir-se ainda o concubinato singular e o plural, conforme haja uma única união ou mais de uma que ligue um dos concubinos ou ambos os concubinos.

Não se confunde o concubinato com o congresso acasional ou descontínuo, pois é da sua essência a união constante.

3. Função sócio-jurídica do concubinato. Múltipla é a função sócio-jurídica do concubinato, sobretudo nos países onde não existe o divórcio.

Com efeito, está para a família ilegítima, mutatis mutandis, na posição do matrimônio para a família legítima.

Assunto mais discutido em teoria do que na prática, força é reconhecer o seu papel construtivo referente à condição das pessoas impedidas de casar-se e que não têm a vocação do celibato.

$\mathrm{Na}$ verdade é o ponto de apoio de muitos que, sem o concubinato, sempre estão sujeitos aos tropeços das uniões ocasionais, as quais, em meio aos muitos problemas que envolvem, entre eles o do próprio lenocínio, mais concorrem para aumentar do que para diminuir a instabilidade e a insegurança psicosomática. 
Em muitos casos, os fatos o hão demonstrado, graças ao concubinato, tem sido possivel reconstruir a vida de muitas famílias sacramentadas pela legitimidade, mas que, efetivamente, se revelaram não só impossíveis, como ainda foco das mais graves e insólitas discórdias.

Não raro, outrossim, filhos que o destino levou a nascerem no torvelinho dos lares desfeitos, passaram a encontrar rumo, aconchego e segurança, graças à união natural, constante e honesta, dos seus pais desquitados.

4. Tendência fundamental do Direito Positivo. Diferentemente do que possa parecer à primeira vista, a preocupação com a condição jurídica da concubina não é recente.

Abstração feita do Direito Romano, especialmente o Justinianeu, onde o concubinato alcançou o que se poderia chamar uma estrutura jurídica, o nosso próprio Direito anterior não o ignorou.

Borges Carneiro (Direito Civil de Portugal, II, p. 153 a 167) trata sob um mesmo título, Do Segundo Matrimônio e do Concubinato, sendo de sua lavra o seguinte ensinamento: "Por Direito comum, o concubinato (diverso do pelicato, do meretriciato, e de simples comércio carnal de homem com mulher) é o estado diturno em que estes vivem juntos como casados, sem contudo o serem"

O mesmo autor cita a Heineccius, IV, $\S 173$, e a STRYcCHIUs, 25, 7, 1, 3.

Enquanto, de um lado, avisadamente, o ordenamento se endereçava contra os "barregueiros casados", do outro, a preocupação do legislador se orientou no sentido de prevenir as incursões da concubina na vida social, e, sobretudo, no patrimônio da família legítima.

Posteriormente ao Código e, mais ainda, às vicissitudes sociais que se seguiram à segunda guerra mundial, entre elas a própria ascensão profissional e política da mulher, com a avalancha dos casais desajustados, o concubinato passou a ser objeto de outra espécie de preocupação.

Não obstante a inegavelmente necessária proteção da família constituída, os olhos dos sociólogos, dos juristas, e sobretudo dos políticos, se voltaram para o aspecto positivo dos direitos do concubinato.

Entre nós, testemunho disso é o Anteprojeto ORLANDo Gomes, de 1963, e o próprio Projeto de Código Civil, de 1965, 
de cuja comissão revisora participou o Ministro Prof. Orosimbo Nonato.

Entretanto, a ostensividade dos direitos atribuídos à companheira (v., por exemplo, art. 668, participação na herança) foi sem dúvida uma das causas da sua retirada do Congresso Nacional (v. Alceu Cordeiro Fernandes e outros, Reforma do Código Civil, p. 61, n. 19, Editora Revista dos Tribunais, 1966).

5. Direitos vedados ao concubinato. A doação do cônjuge adúltero (art. 1.177) ao seu cúmplice pode ser anulada pelo outro cônjuge, ou por seus herdeiros necessários, até dois anos depois de dissolvida a sociedade conjugal (v. Manual, v. 4. ${ }^{\circ}, \mathrm{T}$. II, p. 101, Editora Revista dos Tribunais, 1969).

Por outro lado (art. $1.719, \mathrm{n}$. III), não pode ser nomeada herdeira nem legatária a concubina do testador casado, regra esta que, evidentemente, também se aplica ao concubino da testadora casada.

Dispõe ainda, expressamente, o ordenamento (art. $248, \mathrm{n}$. IV) que a mulher casada pode livremente "reivindicar os bens comuns, móveis ou imóveis, doados ou transferidos pelo marido à concubina (art. 1.177)", direito esse que prevalece "esteja, ou não, a mulher em companhia do marido, e ainda que a doação se dissimile em venda ou outro contrato"

E de dois anos (art. $178, \S 7 .^{\circ}, \mathrm{n}$. vi) a prescrição da ação do cônjuge ou seus herdeiros necessários para anular a doação feita pelo cônjuge adúltero ao seu cúmplice, contado o prazo da dissolução da sociedade conjugal.

Importante proibição, que visa a cercear o concubinato da pessoa casada, é aquela que se relaciona com a incapacidade matrimonial absoluta (art. 183, n. VII) do cônjuge adúltero com o seu co-réu, por tal condenado.

6. Direitos assegurados ao concubinato. Os direitos do concubinato se vão fazendo valer, gradativamente, através das disposições esparsas da legislação extravagante, tendo tido sempre o legislador o cuidado de não mencionar de modo expresso palavras específicas da matéria.

O concubino ou a concubina, por exemplo, podem ser considerados dependentes para os efeitos das isenções de imposto de renda (Lei n. 4.242 , de 17 de julho de 1963, art. 44; Lei n. 4.862 , de 29 de novembro de 1965 , art. $3 .^{\circ}$ ). 
Outrossim, a Lei dos Registros Públicos, n. 6.015, de 31 de dezembro de 1973 , no art. 57, $\$ 2 .^{\circ}$ assegura à mulher solteira, desquitada ou viúva, preenchidos certos requisitos, o direito de alterar o patronímico fazendo acrescentar o do seu companheiro.

A doutrina e a jurisprudência têm atuado no sentido de aumentar os direitos do concubinato (v. EDGARD DE MOURA BitTencourt, $O$ Concubinato no Direito, 2. ${ }^{a}$ edição, 4 volumes, 1969 ; AdAMASTOR Lima, Concubinato e Sociedlade de Fato Subjacente, trabalho forense, Rio, 1956; TEÓFILO CAVALCANTI FILHo, Sobre o direito da concubina de usar o nome do companheiro, in Folha de S. Paulo, de 22 de agosto de 1971).

\section{Os Benefícios Previdenciários Concedidos à Concubina.}

1. Visão geral. A função sócio-jurídica do concubinato, de que já falamos, bem assim a forte pressão da doutrina e da jurisprudência no sentido de, gradativamente, ampliar os respectivos direitos, tem levado o legislador a atender com certa solicitude aos reclamos da consciência social a respeito da matéria, sobretudo numa época em que, entre nós, não existia o divórcio a vínculo e a família ilegítima era o sucedâneo da família legítima de divorciados.

Assim, em meio aos direitos do concubinato a que já aludimos, ressaltaram sempre em importância aqueles concernentes à previdência social da pessoa em estado de concubinato.

Muitas são as normas jurídicas que a têm reconhecido, já no campo da previdência municipal, já no da estadual.

O mesmo, e com maior importância, no federal.

Com efeito, assim se dava, entre outros estatutos, com a Lei Orgânica da Previdência Social, n. 3.807, de 26 de agosto de 1960 , art. $11, \mathrm{n}$. II, do mesmo modo que com o respectivo regulamento, Decreto n. 60.501, de 14 de março de 1967, art. 13, n. II.

Quando do advento da Consolidação das Leis da Preaidência Social, Decreto n. 77.077, de 24 de janeiro de 1976 a matéria alcançou verdadeira feição orgânica, conforme se pode deparar nos arts. 13, n. I; $14, \S \S 1 .^{\circ}, 2 .^{\circ}, 3 .^{\circ}$ e $5 .^{\circ}$; e particularmente no art. 57. 
2. A condição da concubina como dependente. Nos termos do art. $13, \mathrm{n}$. I, da CLPS, a concubina, sob a designação da palavra sinônima de "companheira" é considerada entre os "dependentes DO SEGURADO"

Sua indicação vem em terceiro lugar, após a esposa e o marido inválido.

Além disso, exige o preceito o requisito de que seja "mantida há mais de cinco anos".

A indicação é anterior à dos "filhos de qualquer condição, etc.", bem assim dos demais dependentes contemplados nos incisos II a IV.

0 art. 14 vai mais longe.

Admite a designação de companheira que viva na sua dependência econômica "MESMo NÃO EXCLUSIVA", quando a vida em comum ultrapasse a 5 (cinco) anos.

O $\S 10^{\circ}$ fala das provas da vida em comum e o $\S 2 .^{\circ}$ determina que "A existência de filho em comum supre as condições de designação e prazo"

Não obstante, o $\S 3 .^{\circ}$ estabelece que a designação é ato de vontade do segurado e não pode ser suprida, ressalvada a designação post mortem $\left(\S 4 .^{\circ}\right)$, mediante pelo menos três provas previstas no $\S 1 .^{\circ}$, especialmente a do mesmo domicílio.

$O § 5 .^{\circ}$ cuida da concorrência com os filhos menores havidos em comum com o segurado, salvo se houver expressa manifestação deste em contrário.

3. Benefícios a que tem direito. Os benefícios a que tem direito a concubina são aqueles concernentes aos dependentes e aos beneficiários em geral, conforme a indicação do art. 23 da CLPS.

Dizem respeito aos dependentes:
a) pensão ;
b) auxílio-reclusão;
c) auxílio-funeral ;
$\mathrm{E}$ aos beneficiários em geral:

a) assistência médica, farmacêutica e odontológica;

b) assistência complementar;

c) assistência reeducativa e de readaptação profissional. 
Indiretamente, não se pode deixar de reconhecer, como direito da companheira, alguns benefícios qual, por exemplo, o auxílio-natalidade (art. 44), pago ao segurado "pelo parto de sua esposa ou companheira não segurada, ou de pessoa designada.

Destes benefícios ressalta em importância e complexidade a pensão por morte.

4. A pensão por morte. Este benefício está regulado nos arts. 55 a 61 da CLPS, sendo devido "aos dependentes do segurado, aposentado ou não, que falecer após 12 (doze) contribuições mensais"

De toda a complexa matéria que envolve, apresenta particular importância para o enfoque deste trabalho o problema da concorrência da companheira com a esposa legítima do segurado.

A esse respeito, dispõe $o \S 10^{\circ}$ do art. 57 que $o$ cônjuge ausente NÃo EXCLUIRÁ a companheira do direito à pensão, que só será devida àquele a contar da data da sua habilitação e comprovação de efetiva dependência econômica.

Por outro lado $\left(\S 2 .^{\circ}\right)$ se o cônjuge, desquitado ou não, estiver percebendo alimentos, o valor da pensão alimentícia judicialmente arbitrada the será assegurado, destinando-se o RESTANTE à companheira ou ao dependente designado.

Estas disposições, além daquelas que as completam $\left(\S 3 .^{\circ}\right.$ do art. 57; art. 58, n. II ; art. 58, $\S 1 .^{\circ}$ ) compreendem-se perfeitamente, ao tempo em que foram articuladas, quando em nosso país não existia o divórcio, e a família ilegítima era o refúgio único daqueles que não haviam encontrado caminho na estrutura do lar doméstico legal e tradicional.

\section{O Advento do Divórcio}

1. Conceito de divórcio. A palavra divórcio não é uma dessas palavras da tecnologia estrita do Direito.

Oriunda do latim - divortium-ii (v. SANTos Saraiva, Novíssimo Dicionário Latino Português) CfCero E TITo Lfvio a utilizaram para designar as vertentes que rolam separadas do alto das montanhas divortia aquarum. E o clássico agrônomo Columella a empregou para referir os dias que separam o inverno da primavera - divortium hiemis et veris. 
Diferentemente do que se poderia pensar, não há em latim o verbo divortiare, senão devortere, com acento no $o$, terceira conjugação.

Devortere vem de devertere, que quer dizer verter (encaminhar-se) de modo transverso.

Daí, em latim, divortium querer dizer desvio, caminhos transversos.

Pereira e Souza, no Esboço de hum Diccionario Juridico (Lisboa, 1825), define o divórcio deste modo:

"He a separação dos cônjuges, quanto à cohabitação, e aos bens, em virtude de sentença dada por juiz competente"

Como se vê, esta noção não é propriamente a de divórcio, senão a de desquite, assim vazada em razão do Direito Canônico, que, na informação ao tempo dada pelo autor, "nesta parte se observa entre nós"

De fato reza o Cânon 1.118:

"O matrimônio válido, rato e consumado não pode ser dissolvido por nenhum poder humano e por nenhuma causa, a não ser a morte"

O original é este:

"Matrimonium validum et consummatum nulla humana potestate nullaque causa, praeterquam morte, dissolvi potest"

Cumpre notar, porém, que o Direito Canônico, qual não poderia deixar de ser, agasalha, e substancialmente, a doutrina das nulidades matrimoniais.

O divórcio, tal como o vocábulo é ordinariamente empregado em nossa linguagem jurídica, não se confunde com $o$ desquite, posto que assim o podemos definir:

É A DISSOLUÇÃO DO VÍNCULO MATRIMONIAL EM VIDA DOS CÔNJUGES, MEDIANTE SENTENÇA JUDICIAL, TRANSITADA EM JULGADO.

Esta diversificação é muito bem explicada pelo próprio Direito Canônico.

Conforme FeLIX CAPPELlo (Tractatus de Sacramentis, v. v, "De Matrimônio", § 822) : 
"Duplex distinguitur conjugum separatio, altera quoad vinculum, et dicitur perfecta vel divortium plenum; altera manente vinculo quoad torum, mensam et habitationem, et dicitur imperfecta vel divortium semiplenum"

A tradução é esta:

"A separação dos cônjuges se distingue de modo dúplice. Uma, relacionada com o vínculo e se diz perfeita ou divórcio pleno. Outra, em que o vínculo permanece, relacionada com o leito, a mesa e a habitação e se diz imperfeita ou divórcio semipleno"

2. Paralelo entre o divórcio e institutos afins. $\mathrm{O}$ divórcio não se confunde:

A) Com o desquite;

B) Com a separação de corpos;

C) Com a separação de fato;

D) Com a separação judicial.

Não se confunde com o desquite porque este é o divórcio semipleno, onde a separação não atinge o vínculo.

Não também com a separação de corpos, porque esta é uma medida especial, anterior ao desquite, ou de proteção à personalidade do cônjuge, quando este seja menor e o matrimônio se tenha dado para evitar cumprimento de pena (v. R. LIMONGI França, Manual de Direito Civil, Revista dos Tribunais, 1973, t. I, v. II, p. 261-265).

E diverso o divórcio da separação de fato em virtude de razões múltiplas, bastando assinalar que o divórcio é de jure e não de facto.

E finalmente não é o mesmo que separação judicial, porque, de acordo com o próprio texto constitucional, a separação é anterior ao divórcio, posto que este só se concede após três anos da incidência daquela.

3. Referências históricas. Parece-nos indispensável assinalar que, não obstante as proibições do Novo Testamento (São Paulo, Romanos, 7, 2; Coríntios, 1, 7), a Legislação Mosaica admitia o divórcio.

Com efeito, é assim que está no Cap. 24 do Deuteronômio:

"Se um homem tomar uma mulher, e a tiver consigo, e ela não for agradável diante dos seus olhos por 
qualquer coisa torpe, escreverá um libelo de repúdio, e lhe dará na mão e a despedirá de casa"

No que tange ao Direito Romano, conforme a informação de JöRS-KUNKEL, (Römisches Privatrecht, §§ 175 a 177), o divórcio era amplamente admitido e a sua forma variava de acordo com as espécies de matrimônio.

Assim, se se tratava de matrimônio cum manu, constituído sem solenidade, pela simples constituição da sociedade conjugal, o marido ou o pater familias podiam repudiar a mulher a todo momento, prática à qual, gradativamente, se foram impondo limites de natureza simplesmente ética.

No concernente à coemptio, ato de transmissão do pátrio poder, mediante a mancipatio, perpetrava-se o divórcio por meio da restituição da mulher à pessoa sob cujo pátrio poder se encontrava anteriormente.

Nestes casos, usou-se também do expediente de transmitir o pátrio poder à interposta pessoa que, sobre a mulher, adquiria a potestas, abrindo mão em seguida, para deixá-la em liberdade.

Já quanto à confarreatio, lançava-se mão da difarreatio, ato igualmente solene, baseado no princípio do contrarius actus.

FERRINI assim se expressa a respeito do divórcio romano:

"Il diritto di repudio è larghissimo nel diritto classico; non può essere escluso da patto in contrario (C. 8, $38(39), 2)$.

Anche sotto l'imperatori cristiani esso viene disciplinato, ma non tolto"' (Manuale di Pandette, $4 .^{\mathrm{a}} \mathrm{ed}$., $\S 718)$.

Quanto ao Direito Comparado, é matéria conhecida o fato de que a generalidade dos países adota o divórcio, inclusive nações católicas, como Portugal e a própria Itália.

No que tange ao Brasil, a Constituição de 1891, por insistência de divorcistas, deixou em aberto o problema do divórcio.

Assim, em 1893, o Deputado EDson CoElHo pode apresentar o primeiro projeto de lei, introduzindo o divórcio no Brasil, no que não foi bem sucedido. Secundou-o, já no final do século, LEITE OITICICA, igualmente sem êxito.

De particular importância foi a iniciativa do Senador MARTINHO GARCEZ, datada de 1903, aprovada em primeira discussão, mas que, ao invés de voltar ao Senado, passou a 
integrar a matéria da discussão do Código Civil onde foi derrotada. (v. Homero Pires, "Prefácio" a "O Divórcio e o Anarchismo", de Rui Barbosa, p. II a V, Rio, 1933).

Frustrada tentativa registrou-se em 1908, de autoria do Deputado Alcindo Guanabara.

Em 1934, Deputados e Senadores da Liga Eleitoral Católica fizeram inserir o princípio da indissolubilidade do vínculo, na Constituição de 1934, adquirindo caráter de norma constitucional, com o qual foi mantido até a promulgação da Emenda n. ${ }^{\circ}$, de 1977.

A introdução do divórcio no Brasil dependeu de um sem número de fatores, ligados às mais diversas contingências das transformações do mundo contemporâneo, especialmente no campo da Família.

Mas de modo particular é fruto da liderança do Senador NELSON CARNEIRo, que, em 1947, eleito deputado pela Bahia, entrou com projeto de lei sobre os direitos da concubina, tomou a dianteira na elaboração do estatuto da mulher casada, promulgado em 1962, e, em 1965, cuidou do reconhecimento dos filhos adulterinos.

De 1951 a 1977 propôs seis projetos de anulação de casamento, rejeitados por se considerarem "divórcios disfarçados"

A Emenda Constitucional n. ${ }^{\circ}$, de 1977, tem como concausa próxima a Emenda n. ${ }^{\circ}$ 8, de 14 de abril de 1977, a qual, entre outras disposições, derrogou o art. 48 da Emenda n. ${ }^{\circ}$ 1, de 1969, referente à reforma da Constituição, mudando o quorum de dois terços para o de "maioria absoluta de votos do total de membros do Congresso Nacional" (v. Revista de Direito Civil, Revista dos Tribunais, 1977, v. I, p. 325).

4. Texto da Emenda Constitucional $n .^{\circ} 9$. A íntegra do respectivo texto é a seguinte:

Emenda Constitucional N. ${ }^{\circ} 9$ DE 28 DE JUNHo dE 1977

Dá nova redação ao $\S 10^{\circ}$ do art. 175 da Constituição Federal.

Art. $10^{\circ} O \S 10^{\circ}$ do art. 175 da Constituição Federal passa a vigorar com a seguinte redação:

"Art. 175

$\S 1 .^{\circ} O$ casamento somente poderá ser dissolvido, nos casos expressos em lei, desde que haja prévia separação judicial por mais de três anos" 
Art. 2. $A$ separação, de que trata o $\S 1 .^{\circ}$ do art. 175 da Constituição, poderá ser de fato, devidamente comprovada em Juízo, e pelo prazo de cinco anos, se for anterior à data desta Emenda.

5. O art. $1 .^{\circ}$ da Emenda n..$^{\circ}$ 9. A Emenda Constitucional n. ${ }^{\circ} 9$, de 28 de junho de 1977, é a matriz fundamental do estatuto do divórcio no Brasil, devendo estar nela assentados todos os preceitos de caráter ordinário e regulamentar.

Em primeiro lugar, é preciso que atentemos para o fato de que a própria ementa objetivou derrogar o $\$ 10^{\circ}$ do art. 175 da. Constituição vigente.

Este preceito rezava assim:

“A família é constituída pelo casamento e terá direito à proteção dos Poderes Públicos.

$\S 10^{\circ}$ O casamento é indissolúvel.

Já a Constituição de 1934 dispunha de modo semelhante no art. 144, ao estabelecer que "A família constituída pelo casamento indissolúvel está sob a proteção especial do Estado"

O dispositivo é repetido pelo art. 124 da Carta Constitucional de 1937, bem assim com ligeira modificação, pela Constituição de 1946, art. 163.

O texto da Emenda Constitucional de 1969 é o mesmo da Constituição de 1967.

Do confronto da nova disposição constitucional com a anterior e as demais que a antecederam resulta a adoção inequívoca, em nosso Direito de Família, no Sistema Jurídico e, particularmente, nas estruturas constitucionais, sob a rubrica Da Família, da Educação e da Cultura, da instituição do divórcio, mais precisamente, do divórcio a vínculo.

O princípio da indissolubilidade é revogado, passando a viger, também do plano constitucional, o princípio da dissolubilidade.

Daí resulta que a lei ordinária não poderá trazer nenhuma disposição que atente contra esta regra fundamental, de modo a impedir ou coarctar de modo substancial a dissolubilidade do vínculo matrimonial.

O novo $\S 10^{\circ}$ do art. 175 assinala, porém, que "o casamento somente poderá ser dissolvido nos casos expressos em lei, desde que haja prévia separação judicial por mais de três anos". 
Como se vê, há aí duas espécies de requisitos:

A) Os casos expressos em lei.

B) A prévia separação judicial, por mais de três anos.

Os casos expressos em lei são de natureza ordinária, pois às normas comuns é que compete defini-los e regulá-los, nos limites da Constituição.

Mas a separação judicial é de caráter constitucional.

Assim, cumpre esclarecer, em toda a extensão básica, o que vem a ser essa categoria.

Separação judicial é toda "separatio conjugum" determinada pelo magistrado.

Não se circunscreve ao desquite, devendo incluir-se, na sua expressã̃o inequivocamente ampla, a separação de corpos, exceto aquela concernente à proteção da personalidade de cônjuge menor, em casamento celebrado para evitar cumprimento de pena.

Outrossim, a separação deve ser prévia. Isto é, o divórcio não pode ser requerido diretamente. Pede-se primeiro a separação judicial e, só depois de decorrido o tempo constitucional, é que se postula o divórcio.

A separação deve ser de mais de três anos. Portanto, não basta que seja de três anos completos porque a Constituição exige lapso a mais, podendo resolver-se curialmente com o mínimo de três anos e um dia.

A observação é importante, porque se entende com os requisitos para a abertura do processo de divórcio.

6. O art. $2 .^{\circ}$ da Emenda $n .^{\circ} 9$. Neste preceito, o requisito da separação prévia, definido no $\S 1 .^{\circ}$ do art. 175 , encontra um alargamento do mais profundo significado social.

Não é preciso que a separação seja judicial, como se dá com a separação de corpos e o desquite.

Basta que seja de fato.

É o caso dos cônjuges separados, como se diz na linguagem vulgar, em relação aos quais não se tenha providenciado ou ultimado a separação pronunciada pelo juiz.

Em nosso Manual de Direito Civil, Revista dos Tribunais, 1972, t. I, v. II, p. 269, já havíamos assinalado: 
“ impõe-se como causa do desquite litigioso, a despeito do silêncio da lei, o fato de estarem os cônjuges separados por mais de dois anos contínuos.

Com efeito, na realidade da vida sócio-jurídica, não são raros os casos em que a vida em comum é irreconciliável, e, apenas por capricho, um dos cônjuges recalcitra em acordar o desquite por mútuo consentimento.

A solução é o desquite litigioso baseado na efetividade da separação, garantidos os direitos fundamentais do cônjuge inocente, se os houver'

Temos notícia de que alguns desquites foram propostos com base nesse nosso texto de doutrina, mas não lograram êxito, em virtude do cuidado dos magistrados em não sair da letra rígida da lei, em matéria tão relevante.

Diferentemente do que se tem dado em julgados outros, mesmo em assuntos de Direito de Família, olvidou-se o papel da Doutrina como forma de expressão do Direito, o da Jurisprudência como complemento da lei, e a própria aplicação técnica do art. $4 .^{\circ}$ in fine da Lei de Introdução ao Código Civil (v., de nossa autoria, Principios Gerais de Direito, 2. ${ }^{a}$ ed., Revista dos Tribunais, 1971).

Mas tanto tínhamos razão, e de tal modo se impunham as necessidades oriundas da realidade cotidiana, que aí está a consagração constitucional do pensamento que a respeito fazíamos por transformar-se em norma de direito científico.

O prazo, porém, da separação de fato deverá ser de cinco anos, "se for anterior à data desta Emenda"

De onde duas ilações:

Primeira. O lapso suficiente, posto que a lei não fala em mais de cinco anos, é o de cinco anos completos.

Segunda. Fica em aberto para o legislador ordinário o estabelecimento do prazo para os casos de separação de fato posterior à Emenda. Juízo"

A separação de fato será "devidamente comprovada em

Do ponto de vista constitucional, por força do princípio ubi lex non distinguit, é indiferente que a comprovação judicial se faça em apartado ou ao longo do próprio processo de divórcio. 
Se em apartado, o meio útil de se o fazer é a comumente chamada justificação judicial, que no atual ordenamento processual se denomina simplesmente "justificação", e está regulada nos arts. 861 a 866.

7 A Lei Ordinária do Divórcio. Trata-se da Lei $\mathrm{n}^{\circ}$ 6.515, de 26 de dezembro de 1977, com 54 artigos, divididos em quatro capítulos, subdivididos em seç̧ões, deste modo:

Cap. I. Da Dissolução da Sociedade Conjugal.

Secção I. Dos casos e efeitos da Separação Judicial.

Secção II. Da Proteção da pessoa dos filhos.

Secção III. Do uso do nome.

Seç̧ão IV Dos Alimentos.

Cap. II. Do Divórcio.

Cap. III. Do Processo.

Cap. IV. Das disposições finais e transitórias.

O conteúdo do novo diploma é extremamente complexo, posto que não se limita a tratar da matéria da respectiva rubrica, adentrando-se em disposições sobre herança e filiação.

Daí decorre, segundo se pode aquinhoar ao longo de comentário que tecemos em obra especializada (v. R. LIMongI França, A Lei do Divórcio Comentada e Documentada, Saraiva, 1978), que, efetivamente, ocorreu visceral transformação não só na estrutura da nossa família legítima, como ainda, conforme não podia deixar de ser, em muitos institutos e relações jurídicas afins.

Não fôra, pois, de se esperar, que o concubinato, aquinhoado progressivamente, pela jurisprudência e pela legislação, em função do antigo vínculo indissolúvel, permanecesse incólume.

IV Os Benefícios Previdenciários à Concubina, diante do Estado do Divórcio

1. Perspectivas juridicas do coneubinato. Em nosso Manual de Direito Civil, v. $2 .^{\circ}$, no T. I, dedicado especialmente aos Institutos de Proteção à Personalidade e ao Direito de Família, já em 1972, quando sequer se vislumbrava a inesperada 
possibilidade de promulgação de uma Lei do Divórcio, traçávamos os seguintes enfoques sobre as perspectivas jurídicas do instituto em apreço:

I. Sendo o concubinato um estado de fato, tudo quanto lhe diga respeito deve girar em torno de provas inequívocas, especialmente no que concerne a reconhecimento de direitos dele oriundos.

II. Não raro, há evidente excesso de condescendência para com o concubinato, à face da mentalidade atual referente à matéria.

III. Não basta o concubinato para que haja sociedade de fato de natureza econômica, e, se houver, é preciso provar a medida da participação de cada companheiro.

IV No concubinato, os direitos respeitam não apenas à concubina, senão também ao companheiro, com caráter de plena reciprocidade.

V Não se devem reconhecer aos concubinos direitos melhores ou maiores do que aqueles que se outorgam aos cônjuges.

VI. A sistematização das disposições legais sobre o concubinato é inoportuna, imprudente e injurídica.

A) Inoportuna, porque se trata de uma instituição de fato em plena fase de transformação.

B) Imprudente, porque está inteiramente ligado, o concubinato, aos problemas do divórcio, do desquite e das nulidades matrimoniais, podendo variar o seu interesse jurídico e o seu papel social de acordo com as soluções de jure constituendo que se venham a dar àqueles mencionados problemas.

C) Injurídica, porque o fato de haver julgados sobre a matéria não gera necessariamente regra positiva (v. LIMONGI FrançA, Da Jurisprudência, in Repertório Enciclopédico do Direito Brasileiro; Da Jurisprudência como Direito Positivo, separata da Revista da Faculdade de Direito de São Paulo, 1972).

VII. Em virtude desses e de outros aspectos, a matéria não deve fazer parte do ordenamento civil, senão de disposições de leis extravagantes, prolatadas de acordo com as necessidades e a oportunidade, tendo-se em vista sobretudo o aspecto social do concubinato (v. Anteprojeto, edição de 1973, p. 19).

2. Considerações sobre essas perspectivas quanto ao aspecto previdenciário. $\mathrm{E}$ bem de ver, a matéria dos benefícios 
à concubina, nos termos em que se encontrava na CLPS, antes da Lei do Divórcio, já não se compadecia com o bom Direito e a melhor Justiça.

Dois aspectos particularmente nos chamam a atenção.

O primeiro, quanto à ausência da indispensável "reciprocidade" nas relações entre concubinos, conforme a CLPS.

Nos respectivos arts. 13, 14, 57 aquinhoa apenas a "companheira" e não o "companheiro" o que, evidentemente importa em grosseira iniqüidade, posto que o companheiro é o "marido natural", havendo entre este e o marido, quando um e outro seja inválido, inegável paralelismo.

$\mathrm{O}$ segundo aspecto é o que concerne ao $\S 3 .^{\circ}$ do art. 14 que diz ser a designação de companheira "ato de vontade do segundo e não pode ser suprida"

Ora, sendo concubinato um instituto de fato, é, por razão natural, da prova do fato da convivência e colaboração recíprocas dos companheiros que advém a evidenciação da sua realidade, constituindo-se em despautério jurídico atribuir-lhe o reconhecimento tão-somente ao soberano alvedrio do concubino.

Trata-se de um resquício machístico da nossa legislação, incompatível com o princípio de igualdade substancial de direitos do homem e da mulher, e que, inadmissível no direito comum, com mais razão o é no campo do direito social e previdenciário.

Aliás, o tônus da nossa legislação previdenciária se vê todo alheio aos imperativos dessa conquista dos sistemas jurídicos modernos.

3. O mesmo, ao depois da Lei do Divórcio. Como se viu, ao traçarmos, já em 1972, as perspectivas da matéria, relacionávamo-la com o fato de se dar generoso agasalho ao concubinato à face da então inexistência da separação vincular.

Na verdade, como dissemos, era o concubinato o sucedâneo de um "segundo casamento", de pessoas que, na época, não podiam contrair outras justas núpcias.

Não mais assim, em princípio, com a promulgação da Emenda Constitucional n. ${ }^{\circ} 9$ e da Lei 6.515, de 26 de dezembro de 1977.

Com efeito, os princípios que passam a reger o assunto exsurgem outros e, sobretudo, deixa de ter sentido o amplo 
agasalho de um conúbio ilegítimo, quando a lei oferece aos interessados um meio hábil e conveniente para a regularização sócio-jurídica da situação de fato.

Note-se que, por exemplo, o instituto da legitimação adveio com a finalidade de estimular o bom encaminhamento jurídico dos concubinos não impedidos de se casar.

O mesmo, pois, deve passar a suceder com a legislação fragmentária do concubinato, em particular com a de previdência social.

Os benefícios aos concubinos (no plural) não devem ser outorgados senão quando haja impedimento de casamento ou de divórcio, ou, ainda, prova de recusa de um dos concubinos, quanto à regularização da união de fato.

Para tanto, um dos meios viáveis, fora outorgar ao concubino (masculino ou feminino) o direito de requerer a sua inscrição junto à Previdência Social, incumbindo aos órgãos desta, particularmente através de Assistente Social, indicar a existência ou não de impedimento, bem assim, no caso de inexistência, da recusa da outra parte quanto à regularização do concubinato, transformando-o em matrimônio legítimo.

Essa providência se estribaria em um corolário do princípio da igualdade, porquanto seria ainda um modo de promover os concubinos, fazendo-os subir o degrau sócio-jurídico do honor matrimonii, além do que, em princípio, não convém à coerência do sistema jurídico e à seriedade do Direito de Família, manter e fomentar situações de fato, paralelas ao casamento, quando absolutamente desnecessárias.

\section{Conclusão}

Embora o assunto exija muitas outras considerações, além do enfoque de vários aspectos outros, antolha-se-nos óbvio, desde logo, o fato de que a proteção emprestada ao concubinato, anteriormente à Lei do Divórcio, com o advento desta, perdeu elementos fundamentais da sua razão de ser, ou, de outra forma, adquiriu feições diversas, que o legislador nạ̃o pode ignorar.

Por essa razão, como primeiro tema de debate, submetemos aos especialistas o anteprojeto de lei, com vistas aos atuais arts. 13, 14 e 57 da Consolidação da Previdência Social, posto que esses dispositivos têm sido um dos principais redu- 
tos, a partir de onde se desenvolveu todo um complexo de normas de exceção, que hoje são de molde a configurar um verdadeiro estatuto do concubinato.

$O$ texto é o seguinte, sub censura:

LEI n. ${ }^{\circ}$.de. .de.

Art. $1 .^{\circ}$. Os arts. 13,14 e 57 da Consolidação das Leis da Previdência Social passam a vigorar com as seguintes derrogações:

Art. 13. Consideram-se dependentes do segurado, para os efeitos da Previdência Social:

I. a esposa, o marido inválido, a companheira, o companheiro inválido, estes dois últimos com mais de cinco anos de convivência, os filhos de qualquer condição menores de 18 (dezoito) anos ou inválidos e as filhas solteiras de qualquer condição menores de 21 (vinte e um) anos ou inválidas.

II. a pessoa designada, se do sexo masculino, só poderá ser menor de 18 (dezoito) anos ou maior de 60 (sessenta) anos, ou inválida;

III. o pai inválido e a mãe;

IV os irmãos de qualquer condição menores de 18 (dezoito) anos ou inválidos e as irmãs solteiras de qualquer condição menores de 21 (vinte e um) anos ou inválidas.

$\S 1 .^{\circ} \quad$ A existência de dependente de qualquer das classes dos itens I e II exclui do direito às prestações os das classes subseqüentes.

§ 2. $\quad$ Equiparam-se aos filhos, nas condições do item I, mediante declaração escrita do segurado:

a) o enteado;

b) o menor que, por determinação judicial, se ache sob sua guarda;

c) o menor que se ache sob sua tutela e não possua bens suficientes para o próprio sustento e educação.

$\S 3 .^{\circ} \quad$ Inexistindo esposa, ou marido inválido, com direito às prestações, a pessoa designada poderá, mediante declaração escrita do segurado, concorrer com os filhos deste.

$\S 4 .^{\circ}$. Não sendo o segurado civilmente casado, será considerada tacitamente designada a pessoa com quem ele se tenha casado segundo rito religioso, presumindo-se feita a declaração prevista no $\S 3 .^{\circ}$. 
$\S 5 .^{\circ}$ Mediante declaração escrita do segurado, os dependentes do item III poderão concorrer com a esposa, a companheira, ou marido ou companheiro inválido, ou com a pessoa designada na forma do $\S 4 .^{\circ}$, salvo se existir filho com direito às prestações.

Art. 14. E lícita a designação, pelo segurado de um e outro sexo, de companheira ou companheiro que viva na sua dependência econômica, quando a vida em comum ultrapasse cinco anos.

(Obs. - Suprima-se a expressão "mesmo não exclusiva", da legislação em vigor).

$\S 1 .^{0}$ São provas da vida em comum o mesmo domicílio, conta bancária conjunta, procuração ou fiança reciprocamente outorgadas, encargo doméstico evidente, registro de associação de qualquer natureza onde figure a companheira, ou companheiro, como dependente, ou qualquer outra capaz de constituir elemento de conviç̧ão.

$\S 2 .^{\circ} \quad$ A existência de filho em comum supre as condições de designação e de prazo.

$\S 30^{\circ} \quad$ Suprima-se.

$\S 4 .^{\circ}$ Passa a ser o $\S 3 .^{\circ}$.

$\S 4 .^{\circ}$ A companheira, ou companheiro designado, concorrerá com os filhos menores havidos em comum com o segurado, salvo se houver expressa manifestação deste em contrário.

$\S 5 .^{\circ}$. Os beneficios à companheira, ou ao companheiro não serão conferidos, senão quando haja impedimento de casamento, ou de divórcio com casamento posterior ou, ainda, prova de recusa do segurado quanto à legalizaçāo da uniāo de fato.

Art. 57. A concessão da pensão não será adiada pela falta de habilitação de outros possíveis dependentes, e qualquer inscrição ou habilitação posterior que implique exclusão ou inclusão de dependentes só produzirá efeito a contar da data em que for feita.

$\S 10^{\circ}$ O cônjuge ausente não excluirá a companheira, ou companheiro designado, do direito à pensão, que só será devida àquele a contar da data de sua habilitação e comprovação de efetiva dependência econômica.

$\S 2 .^{\circ}$. Se o cônjuge, desquitado ou não, estiver percebendo alimentos, o valor da pensão alimentícia judicialmente arbitrada lhe será assegurado, destinando-se o restante à companheira, companheiro ou ao dependente designado. 
$\S 3 .^{\circ}$ A pensão alimentícia será reajustada na mesma ocasião e nas mesmas bases do reajustamento da pensão.

Art. 2. ${ }^{\circ}$. Esta lei entrará em vigor, com efeito imediato, na data da publicação.

Voltamos a asseverar que esta colocação está longe de ter foros de definitiva, razão pela qual a submetemos à douta consideração dos senhores especialistas. 